EUROPA REGIONUM TOM XXVIII ROK 2016

DOI: $10.18276 /$ er.2016.28-07

\author{
MIKOŁAJ JALINIK \\ Zamiejscowy Wydział Leśny Politechniki \\ Białostockiej w Hajnówce
}

\title{
Ruch turystyczny na obszarze Puszczy Białowieskiej w świetle badań
}

\section{Wprowadzenie}

D uszcza Białowieska jest szczególnym obszarem pod względem walorów przyrodniczych, krajobrazowych i kulturowych. Potencjał ten jest głównym czynnikiem pobudzającym do rozwoju turystki na tym obszarze. Jest także szczególnym obszarem pod względem funkcjonowania infrastruktury turystycznej, ale nie w pełni dostrzeganej przez władze samorządowe.

Ruch turystyczny zależy od wielu czynników, ale głównie od występujących walorów i atrakcji turystycznych, a także zainteresowanych usługobiorców wymienionym obszarem. Najczęściej jednak są to osoby podróżujące w celach turystycznych i rekreacyjnych, w mniejszym zakresie przyjeżdżają w celach naukowych, jak wykazały badania, które zostały przeprowadzone w maju i czerwcu 2016 r. Ruch turystyczny na obszarze Puszczy Białowieskiej, to wszelkie migracje osób podróżujących z województwa podlaskiego, a w mniejszym stopniu spoza innych województw i zagranicy. W badaniach ruchu turystycznego najliczniejszą grupę stanowili mężczyźni i ogólnie osoby w wieku od 30 do 50 lat.

Badania wykazały, że Białowieża, jak i Puszcza Białowieska niewiele atrakcji ma do zaoferowania. Najczęściej goście korzystali ze spacerów i przejażdżek rowerami i wozami konnymi. To na co oczekują turyści, to przede wszystkim brak atrakcji przy spędzaniu czasu wolnego w godzinach popołu- 
dniowych i wieczornych. Jest to kolejny element wpływający na rozwój ruchu turystycznego.

Celem opracowania jest analiza ruchu turystycznego na obszarze Puszczy Białowieskiej oraz wskazanie możliwości jego dalszego rozwoju, a także niedociągnięć organizacyjnych w zarządzaniu obszarem.

\section{Podstawowe pojęcia związane z ruchem turystycznym}

Pojęcie ruchu turystycznego jest różnie interpretowane $\mathrm{w}$ literaturze przedmiotu. $Z$ ruchem turystycznym ściśle związanych jest wiele pojęć i definicji, takich jak: turystyka, turysta, ruch turystyczny i wiele innych. Współczesna turystyka obejmuje ogół czynności i osób, które podróżują i przebywają w celach wypoczynkowych, zawodowych lub innych, nie dłużej niż rok bez przerwy poza swoim codziennym otoczeniem, $\mathrm{z}$ wyłączeniem wyjazdów, w których głównym celem działalności jest działalność zarobkowa ${ }^{1}$.

Pojęcie turysta pojawiło się dopiero w XVIII w., w konsekwencji stosowania określenia grand tour dla podróży podejmowanych przez Anglików do kontynentalnej części Europy, spopularyzowanych pod koniec XVIII w. (głównie do Francji, Niemiec i Włoch), których to uczestników określano turystami (tourists) ${ }^{2}$. Obecnie, zgodnie z zaleceniami UN WTO, wszystkie osoby opuszczające swoje miejsce zamieszkania $\mathrm{w}$ celu odbycia podróży określa się mianem podróżnych. Wśród nich można wyróżnić odwiedzających i innych podróżnych.

Międzynarodowa Akademia Turystyki w Monte Carlo określiła ruch turystyczny jako podróże podejmowane dla przyjemności, wypoczynku lub leczenia - pieszo lub jakimkolwiek środkiem komunikacji. Do ich zakresu nie należą podróże w celach zarobkowych ani w celach zmiany miejsca stałego zamieszkania (osiedlania się) ${ }^{3}$. Właściwym miernikiem ruchu turystycznego jest określenie przemieszczania się ludzi, które nie jest wymuszone przez czynniki zewnętrzne - ludzie zmieniają miejsce pobytu, swoje środowisko, rytm życia dobrowolnie bez przymusu. Należy stwierdzić, że ruch turystyczny odnosi się do określonego obszaru, kierunku, okresu, w którym trwa.

Według Łobożewicza i Bieńczyka, ruch turystyczny jest zjawiskiem złożonym i umożliwia bardzo różnorodny podział według różnych kryteriów. Najczę-

\footnotetext{
${ }^{1}$ Terminologia turystyczna. Zalecenia WTO, Warszawa 1995, s. 5

${ }^{2}$ B. Meyer, Obstuga ruchu turystycznego, PWN, Warszawa 2006, s. 11.

${ }^{3}$ W.W. Gaworecki, Turystyka, PWN, Warszawa 2010, s. 17.
} 
ściej używanym kryterium podziału ruchu turystycznego jest czas trwania pobytu $^{4}$. Gołembski interpretuje ruch turystyczny jako ogół dobrowolnych, czasowych przemieszczeń przestrzennych poza miejsce stałego zamieszkania, podejmowanych dla realizacji celów rekreacyjnych, poznawczych, zdrowotnych i rozrywkowych ${ }^{5}$.

Zgodnie z zaleceniami UN WTO, wszystkie osoby opuszczające swoje miejsce zamieszkania $\mathrm{w}$ celu odbycia podróży określa się mianem podróżnych. Wśród nich można wyróżnić odwiedzających i innych podróżnych ${ }^{6}$. Odwiedzający, to osoba podróżująca do miejscowości znajdującej się poza codziennym otoczeniem, na czas nie dłuższy niż dwanaście miesięcy, jeśli podstawowym celem podróży nie jest podjęcie działalności zarobkowej wynagradzanej w odwiedzanej miejscowości ${ }^{7}$. Pozostali podróżni, nie spełniający tego kryterium, są określani mianem innych podróżnych. Wśród odwiedzających można wyróżnić grupę odwiedzających międzynarodowych, do której należą osoby podróżujące do kraju niebędącego ich stałym miejscem zamieszkania oraz odwiedzających krajowych, czyli osoby podróżujące w obrębie kraju swojego stałego zamieszkania. W zależności od długości pobytu wśród odwiedzających (międzynarodowych i krajowych) można wyróżnić turystów, czyli osoby spędzające przynajmniej jedną noc w obiektach noclegowych w odwiedzanej miejscowości oraz odwiedzających jednodniowych, którzy nie korzystają z noclegu w żadnych obiektach noclegowych w odwiedzanej miejscowości ${ }^{8}$.

W 1963 r. Komisja Statystyki ONZ ustaliła, że w statystykach dotyczących turystyki międzynarodowej należy wyodrębnić trzy rodzaje podróżnych:

- odwiedzających;

- turystów;

- wycieczkowiczów 9 .

Ustalono wówczas, że określenie odwiedzający obejmuje wszystkie osoby przybywające do kraju nie będącego krajem ich stałego zamieszkania, w jakimkolwiek celu, $\mathrm{z}$ wyjątkiem wykonywania $\mathrm{w}$ tym kraju odpłatnie zawodu. Odwiedzających podzielono $\mathrm{na}^{10}$ :

\footnotetext{
${ }^{4}$ T. Łobożewicz, G. Bieńczyk, Podstawy turystyki, WSE, Warszawa 2001, s. 88.

${ }^{5}$ Ibidem.

${ }^{6}$ B. Meyer, Obstuga ruchu....., s. 11.

${ }^{7}$ Ibidem.

${ }^{8}$ Ibidem.

${ }^{9}$ A. Panasiuk, Ekonomika turystyki, (red.), PWN, Warszawa 2007, s. 27.

${ }^{10}$ Ibidem.
} 
- turystów - odwiedzających, którzy przebywają w odwiedzanym kraju co najmniej 24 godziny, których cele podróży mogą być ujęte w następujące grupy:

a) wykorzystanie czasu wolnego, rozrywka, wakacje, zdrowie, studia, religia lub sport,

b) interesy, sprawy rodzinne, misje, zjazdy.

- wycieczkowiczów - odwiedzających, którzy przebywają w danym kraju krócej niż 24 godziny (łącznie z uczestnikami rejsów morskich).

Definicje są istotne dla każdego podróżującego, natomiast osoby, które nie mają styczności z turystyką mogą je poznać lub przypomnieć $\mathrm{w}$ jakiej roli występują. Niektóre pojęcia mogą być istotne przed wyborem oferty turystycznej, nie tylko przez turystę, ale i osoby nie związane $\mathrm{z}$ ruchem turystycznym.

\section{Atuty Puszczy Białowieskiej}

Jedynym w swoistym rodzaju obszarem o unikatowych walorach turystycznych jest region Puszczy Białowieskiej. Puszcza Białowieska jest obszarem specyficznym pod względem turystyczno-rekreacyjnym i jedyną na naszym kontynencie naturalną ostoją żubra. Jest to kompleks leśny o powierzchni 1250 $\mathrm{km}^{2}$, z czego w polskich granicach znajduje się $580 \mathrm{~km}^{2}$. Pozostała część położona jest na terenie Białorusi. Dlatego na jej terenie utworzono 20 rezerwatów, które zajmują powierzchnię 3429,65 ha. Najcenniejszym jednak na tym obszarze jest Białowieski Park Narodowy, który powstał w 1921 r., jednak podstawy prawne uzyskał dopiero w 1932 r., a zatwierdzony został rozporządzeniem Rady Ministrów w 1947 r. z powierzchnią 5348 ha. Kompleks ten jest usytuowany na pograniczu Europy Środkowej i Europy Wschodniej ${ }^{11}$. W Puszczy Białowieskiej powstał jako jedyny z siedmiu na świecie i trzech w Europie. Obecnie zajmuje powierzchnię 10502 ha i obejmuje najlepiej zachowaną część Puszczy Białowieskiej, z tego $45 \%$ podlega ochronie ścisłej ${ }^{12}$.

Z uwagi na unikatowe walory przyrodnicze, Białowieski Park Narodowy został uznany przez UNESCO w 1977 r. za Światowy Rezerwat Biosfery, a od

\footnotetext{
${ }^{11}$ Białowieski Park Narodowy, Wyd. BPN, Białowieża 2009

${ }^{12}$ Informacja Dyrekcji Białowieskiego Parku Narodowego, Białowieża 2013
} 
1979 r. - jako jedyny polski obiekt przyrodniczy znajdujący się na liście Światowego Dziedzictwa Ludzkości $i^{13}$.

W okresie przedwojennym Puszcza Białowieska była miejscem pobytu i polowań wielu książąt litewskich, królów polskich i carów rosyjskich. Dużym zainteresowaniem wśród osób zwiedzających Puszczę, cieszy się Muzeum Przyrodniczo-Leśne $\mathrm{z}$ wieżą widokową (panorama polany białowieskiej, Białowieży i obszar ochrony ścisłej). Jest ono jednym z najstarszych muzeów w polskich parkach narodowych. Jego tradycje sięgają okresu międzywojennego, a w swoich zbiorach posiada wiele cennych kolekcji naukowych i rzadkich okazów ptaków, ssaków i owadów. Bardzo interesującym produktem turystycznym jest także skansen - zespół budownictwa drewnianego Rusinów Podlasia. To prywatny skansen położony w Białowieży, na terenie dawnej wsi Kropiwnik, zniszczonej podczas II wojny światowej.

Obiektem, który wzbudza zainteresowanie wśród turystów jest Rezerwat Pokazowy Zwierząt zajmujący powierzchnię 27,9 ha. Został powołany w $1936 \mathrm{r}$. w miejscu, gdzie założono rezerwat hodowli konika typu tarpan. Po drugiej wojnie światowej rezerwat został rozbudowany i obok tarpanów umieszczono w nim żubry, a także umożliwiono dla osób chętnych jego zwiedzanie. Obecnie rezerwat może poszczycić się obecnością wszystkich dzikich kopytnych gatunków zwierząt żyjących w Puszczy Białowieskiej, do których należy zaliczyć: żubry, jelenie, sarny, dziki, tarpany, żubronie i wilki ${ }^{14}$. Należy także dodać, że na obszarze Puszczy Białowieskiej dobra czystość wód (występuje II klasa), a tradycyjną formą rekreacji w okresie zimowym są organizowane kuligi i ogniska. W okresie letnim z kolei bardzo popularne są przejażdżki bryczką po Białowieży i Białowieskim Parku Narodowym oraz ogniska na polanach przy akompaniamencie muzyki akordeonowej.

Wśród produktów turystycznych ważnym elementem są walory kulturowe, w które region Puszczy Białowieskiej szczególnie jest bogaty. Różnorodność etniczna i wyznaniowa tego obszaru znalazła odzwierciedlenie w architekturze sakralnej. Są to bogato zdobione, drewniane i murowane cerkwie, kościoły i kapliczki przydrożne, cmentarze różnych religii. W Białowieży jest także organizowanych wiele imprez rozrywkowych, między innymi: Festiwal Przyrody

${ }^{13}$ M. Jalinik, Białowieski Park Narodowy - turystyczna atrakcja wieloaspektowa, w: K. Michałowski, B. Malinowska (red.), Markowy produkt turystyczny w pólnocno-wschodniej Polsce, Wydawnictwo Politechniki Białostockiej, Biały stok 2004, s. 51.

${ }^{14}$ Informacja..., 2013. 
„Żubrowisko”, Noc Kupały, Peretocze, Festyn Miodowy, Festiwal Muzyki Puszczy Białowieskiej i wiele innych o regionalnym zasięgu. Imprezy kulturalne i folklorystyczne podnoszą atrakcyjność turystyczną, umożliwiając turystom $\mathrm{z}$ innych regionów kraju oraz turystom zagranicznym, poznanie tradycji etniczno-kulturowych mieszkańców analizowanego obszaru.

Oryginalną atrakcją Puszczy Białowieskiej jest turystyczna kolejka wąskotorowa, kursująca na trasie Hajnówka - Topiło. Wzdłuż trasy rozmieszczonych jest wiele przystanków edukacyjnych prezentujących najciekawsze zbiorowiska leśne $\mathrm{z}$ ich charakterystyczną florą. Przed transformacją systemu społecznogospodarczego kraju, takie kolejki użytkowane były na obszarze całej Puszczy Białowieskiej. Niestety, większość z nich uległa całkowitej likwidacji, a ocalała jest doskonałą atrakcją turystyczną, ale tylko w okresie letnim.

Przez obszar Puszczy przepływa rzeka Narewka, Leśna i Hwoźna, które również stanowią atrakcję dla turystów i wędkarzy, a w otulinie Puszczy Białowieskiej znajduje się zalew „Bachmaty” i „Repczyce”. Mimo pozornej jednolitości warunków siedliskowych, wynikających $\mathrm{z}$ równinnego charakteru obszaru puszczy, świat roślinny, a w tym przede wszystkim skład gatunkowy drzewostanów reprezentuje się jako różnorodność form i odmian mozaiki leśnej ${ }^{15}$.

\section{Metodyka badań}

Badania przeprowadzono $\mathrm{w}$ obiektach noclegowych funkcjonujących w gminie Białowieża, która położona jest w całości na obszarze Puszczy Białowieskiej. Dobór obszaru badań był celowy. Celem było zbadanie pobytu turystów, którzy przynajmniej jedną dobę przebywali na obszarze Puszczy Białowieskiej, korzystając z noclegu i wyżywienia. W badaniach nie uwzględniono tych turystów, którzy przebywali na obszarze Puszczy Białowieskiej mniej niż dobę. Wykaz obiektów i ich lokalizację uzyskano z Urzędu Gminy w Białowieży. Według uzyskanych danych w maju i czerwcu 2016 r. na badanym obszarze prowadziło działalność 77 obiektów noclegowych (hotele, pensjonaty, gospodarstwa agroturystyczne, kwatery prywatne, zajazdy, kempingi).

Badania przeprowadzono wśród właścicieli obiektów noclegowych i przebywających na wypoczynku turystów przy wykorzystaniu metody sondażu dia-

15 B. Poskrobko, Rejon Puszczy Białowieskiej. Mieszkańcy - Środowisko - Gospodarka, (red), Wydawnictwo. Politechniki Białostockiej, Białystok 1996, s. 144. 
gnostycznego, w tym techniki ankietowej. Do właścicieli obiektów noclegowych skierowano 80 narzędzi badawczych i 90 do turystów. Ankiety zawierały odpowiednio 32 pytania (właściciele obiektów) i 36 pytań (turyści) typu zamkniętego i otwartego. Z prośbą o udzielenie odpowiedzi zwrócono się do wszystkich właścicieli obiektów i przebywających na wypoczynku turystów. Spośród właścicieli obiektów, ośmiu ankieterów nie udzieliło odpowiedzi i dziesięciu turystów.

Pytania zawarte w ankiecie badawczej dotyczyły: motywu wyboru Białowieży i Puszczy Białowieskiej do odwiedzania i wypoczynku; celu przyjazdu do Białowieży; wieku i płci osób odwiedzających; czym kierowali się odwiedzając Białowieżę; miejsca stałego zamieszkania; wykształcenia; zainteresowania; znajomości języków obcych; z jakich regionów i krajów pochodzili turyści; oceny infrastruktury turystycznej i rekreacyjnej; okresu przyjazdu; oczekiwań turystów podczas pobytu w gminie Białowieża; długości pobytu w Białowieży; pozytywnej i negatywnej oceny wypoczynku w Białowieży i Puszczy Białowieskiej pod względem atrakcyjności.

Na podstawie uzyskanych w badaniach danych wskazano, jak atrakcyjna jest Białowieża i Puszcza Białowieska oraz jaki jest okres pobytu gości i czym uzasadniają swój pobyt. Była to jednocześnie odpowiedź, jaki jest ruch turystyczny na badanym obszarze oraz jakie są oczekiwania gości.

\section{Wyniki badań}

Ruch turystyczny na obszarze Puszczy Białowieskiej przebiegał różnie w poszczególnych latach. Badania wykazały, że w roku 2016 zwiększyła się liczba odwiedzających gminę Białowieża w porównaniu z rokiem 2015 i pozostałymi latami. Tak stwierdzili właściciele obiektów noclegowych. Wpłynęła na to informacja $\mathrm{w}$ mediach związana $\mathrm{z}$ kornikiem drukarzem, który zaatakował świerk, a jednocześnie wywołało to zainteresowanie mieszkańców Polski Pus zczą Białowieską. Kolejnym powodem są ataki terrorystyczne w wielu krajach europejskich i pozaeuropejskich w związku z czym znaczna liczba osób nie zdecydowała się na wyjazd do tych krajów i ostatecznie wybrała Białowieżę. Według danych uzyskanych od właścicieli obiektów noclegowych gminy Białowieża, Puszczę Białowieską najwięcej odwiedza turystów z województwa: mazowieckiego, łódzkiego, wielkopolskiego i śląskiego.

Są to osoby, które przynajmniej jeden tydzień korzystali z usług noclegowych i żywieniowych. Poza mieszkańcami z Polski, najwięcej turystów odwie- 
dziło Puszczę Białowieską z Niemiec, Francji, Rosji i Hiszpanii. Wśród pozostałych narodowości ankieterzy wymieniali turystów z: Białorusi, Stanów Zjednoczonych, Holandii, Austrii, Japonii i Wielkiej Brytanii ${ }^{16}$. Odnośnie Białorusi ankietowani stwierdzili, że ich interesowała głównie turystyka szopingowa, a nie wypoczynek w Białowieży. Był to ich główny powód przyjazdu na obszar Puszczy Białowieskiej. Okresy pobytu na obszarze Puszczy Białowieskiej przedstawia rys. 1.

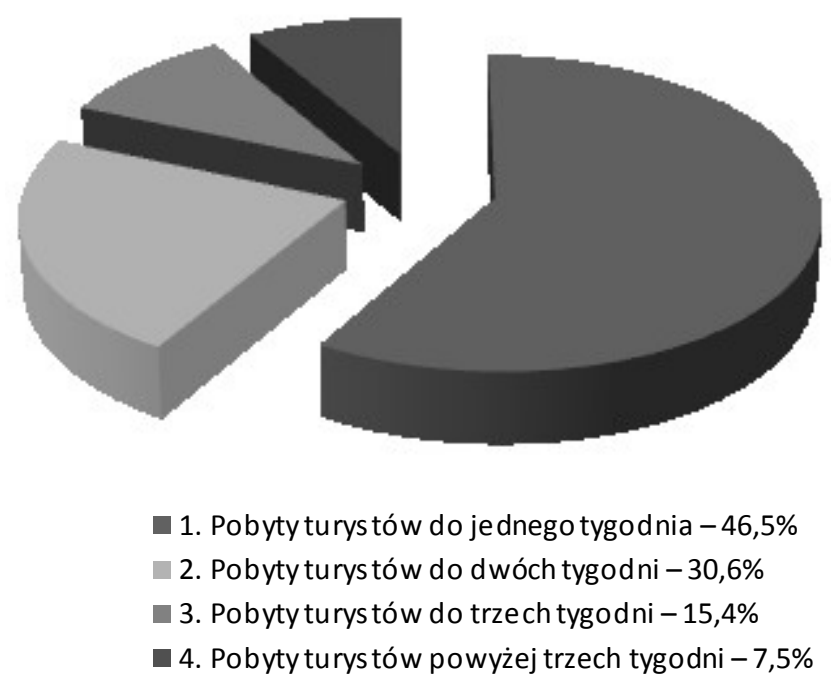

Rysunek 1. Pobyty turystów w obiektach noclegowych w gminie Białowieża

Najwięcej chętnych odwiedza Białowieżę i Puszczę Białowieską w przedziale wiekowym od 36-45 lat z wykształceniem wyższym i średnim, mających zatrudnienie $\mathrm{w}$ instytucjach i zakładach produkcyjno-usługowych (rys. 2). Wśród odwiedzających $64 \%$ stanowili mężczyźni, a 36\% kobiety. Świadczy to o tym, że nie przeważały małżeństwa, które zazwyczaj planują kilkunastodniowy rodzinny wypoczynek, a w tym przypadku były to krótkie „wypady krajoznawcze".

${ }^{16}$ Dane na podstawie wyników badań. 


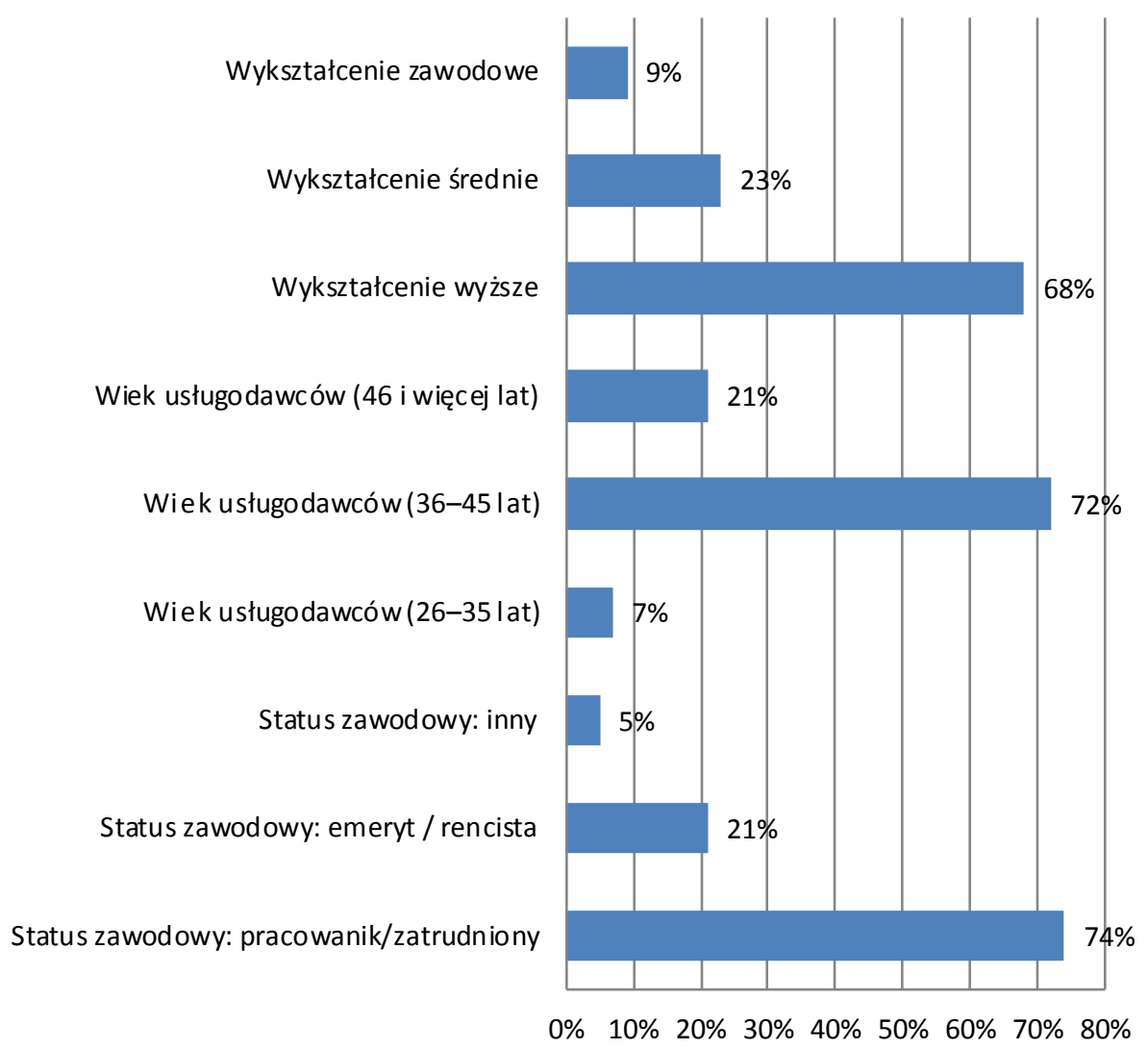

Rysunek 2. Charakterystyka odwiedzających Białowieżę i Puszczę Białowieską

$\mathrm{Na}$ podkreślenie ze strony usługobiorców zasługuje to, że zaobserwowano coraz większą znajomość języków obcych przez przewodników turystycznych w Białowieży. Wśród języków obcych przewodnicy najczęściej porozumiewali się $\mathrm{z}$ turystami $\mathrm{w}$ języku angielskim, niemieckim i rosyjskim. Znajomość języków obcych przez przewodników, pilotów i właścicieli obiektów noclegowych i żywieniowych również pozytywnie wpływa na zainteresowanie danym obszarem i świadczeniem usług turystycznych ${ }^{17}$. Na pytanie, czy planuje Pan/Pani ponowny przyjazd do Białowieży 75\% ankietowanych odpowiedziało „tak”, natomiast czy Białowieżę i Puszczę Białowieską uważasz za atrakcyjną turystycznie, $79 \%$ uznało za atrakcyjną.

${ }^{17}$ M. Jalinik, Doradztwo $w$ działalności turystycznej, Wyd. EkoPress, Białystok-Hajnówka 2016, s. 123 . 
Pomimo, że znaczący odsetek uważa obszar Puszczy Białowieskiej za atrakcyjny, to kolejne pytanie typu otwartego dotyczyło: co zniechęca usługobiorców do wypoczynku na wymienionym obszarze? Odpowiedzi przedstawia rys. 3 .

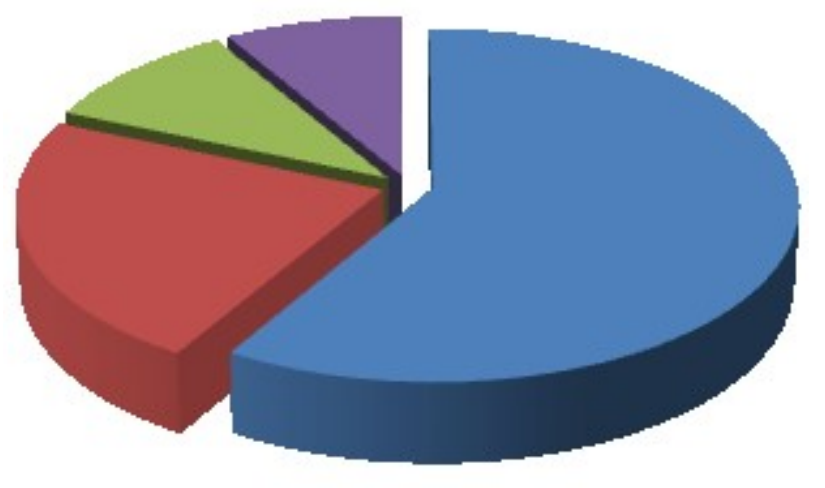

$$
\begin{aligned}
& \text { Zbyt mało a trakcji turys tycznych }-36 \% \\
& \text { Wys tepowanie komarów w okresie letnimi wiosennym -28\% } \\
& \text { Ni ezadawalające połączenie komunikacyjne - } 20 \% \\
& \text { Nis ki standard obiektów noclegowych }-16 \%
\end{aligned}
$$

Rysunek 3. Ocena atrakcyjności Białowieży i Puszczy Białowieskiej

Większość ankietowanych uważa, że aby zachęcić turystów do odwiedzania Białowieży i Puszczy Białowieskiej należy zwiększyć liczbę atrakcji turystycznych. Sugerowano, że mógłby powstać park linowy, boisko sportowe z bieżnią i możliwością gier zespołowych, basen kryty, kręgielnia, wypożyczalnia rowerów i sprzętu wodnego, sprzętu zimowego. Są to podstawowe obiekty i atrakcje, które mogłyby przyciągnąć znaczną liczbę turystów. Pomimo występowania komarów, to jednak część ankietowanych uznała, że obecnie są środki zapobiegające temu zagrożeniu i z tym można poradzić. Postulowano aby przywrócić połączenie kolejowe, wówczas przyjezdni beztrosko mogliby przyjechać i odjechać bez większych obciążeń psychicznych, a nawet w czasie podróży lepiej smakowałyby regionalne napoje alkoholowe. Zwrócono uwagę, że pomimo istniejącego połączenia autobusowego, to i tak jest zbyt mało przejazdów i w dodatku są o niskim standardzie, co pogarsza komfort jazdy. 
Zazwyczaj każdy turysta ogranicza się do wypowiedzi nie o tym co jest dobre, ale bardziej dostrzega to, co należałoby poprawić i źle funkcjonuje. W gminie Białowieża funkcjonują dwa obiekty hotelarskie (jeden czterogwiazdkowy i jeden trzygwiazdkowy). Pozostałe obiekty noclegowe nie zadawalają turystów pod względem komfortu. Tak wykazały badania ankietowe. Celem przyjazdu turystów do Białowieży było poznanie/odwiedzenie:

- Białowieży;

- Rezerwatu Pokazowego Żubrów BPN;

- Muzeum Przyrodniczo-Leśnego BPN;

- Rezerwatu Ścisłego BPN;

- „Miejsc Mocy” w Nadleśnictwie Białowieża;

- „Szlaku Dębów Królewskich” w Nadleśnictwie Białowieża;

- „Żebra Żubra” w Nadleśnictwie Białowieża;

- Kolejki Leśnej w Nadleśnictwie Hajnówka;

- Zalewu Siemianówka;

- białoruskiej części Puszczy Białowieskiej - przejścia granicznego.

Turystyka na obszarach przyrodniczo cennych, objętych ochroną oraz na ich pograniczu budzi wiele kontrowersji i niepokojów, zarówno osób zajmujących się ochroną przyrody, jak i osób odpowiedzialnych za rozwój gospodarczy, dostrzegających w turystyce szanse na rozwój regionu. Jest potrzeba wypracowania takiej koncepcji zagospodarowania turystycznego obszaru, by dawała ona maksymalne korzyści dla lokalnej społeczności przy minimalnych zagrożeniach walorów przyrodniczych i kulturowych.

Największym zainteresowaniem wśród turystów jest Białowieski Park Narodowy, który największa liczba osób odwiedziła w latach 1997-2015 (rys. 4).

Wśród odwiedzających najliczniejszą grupę stanowili: leśnicy, pracownicy instytucji związanych z ochroną przyrody, uczestnicy seminariów naukowych, konferencji, kongresów, studenci uczelni wyższych wydziałów leśnych, przyrodniczych, turystycznych, ekipy telewizyjne, fotoreporterzy, dziennikarze $\mathrm{z}$ kraju i zagranicy, miłośnicy przyrody (np. birdwatching) ${ }^{18}$.

${ }^{18}$ A. Gierasimiuk, Udostępnianie turystyczne BPN.....Hajnówka 2015. 
Statystyka w BPN

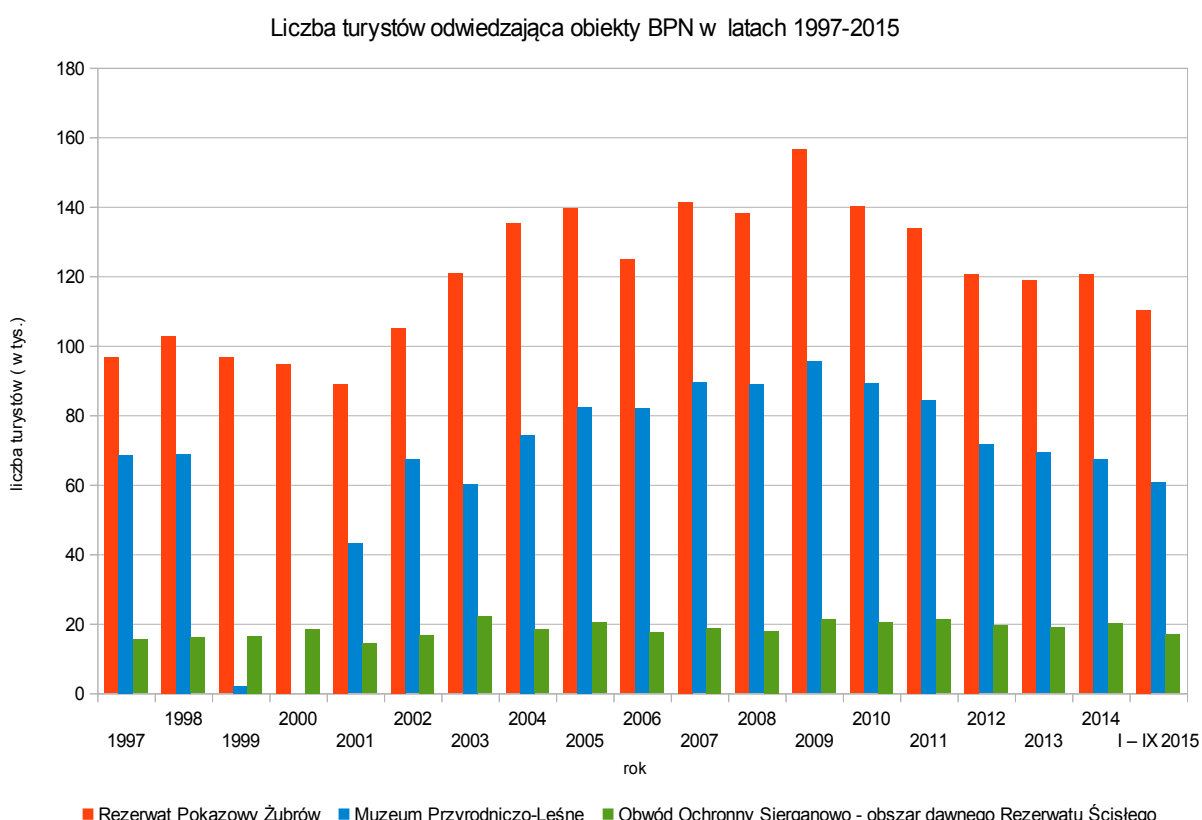

Rysunek 4. Liczba odwiedzających Białowieski Park Narodowy

Źródło: A. Gierasimiuk, Udostępnianie turystyczne BPN, zagospodarowanie-problemy-plany na przyszłość, Centrum Naukowo Badawcze ZWL w Hajnówce, Hajnówka 2015.

\section{Podsumowanie}

Zwiększająca się popularność wyjazdów turystycznych, jako formy spędzania czasu wolnego przyczynia się do stałego zwiększania się liczby turystów. Rozwój cywilizacyjny powoduje, że sukcesywnie wzrasta zainteresowanie wypoczynkiem na obszarach o nieskażonym środowisku. Wynika to przede wszystkim $\mathrm{z}$ postępującej urbanizacji, zmian w strukturze zawodowej mieszkańców na korzyść pracy umysłowej, poprawy sytuacji ekonomicznej. Znaczącym czynnikiem przyciągającym turystów do gminy Białowieża i Puszczy Białowieskiej są walory przyrodnicze, krajobrazowe i kulturowe, a głównie obszary leśne. Należy pamiętać, że obszary leśne są dla ludzi, ale trzeba z nich umiejętnie korzystać w celu poprawy zdrowia fizycznego i psychicznego, nie naruszając zasad rozwoju zrównoważonego. 
Wyniki badań wykazały, że na obszarze Puszczy Białowieskiej należy dążyć do zwiększenia atrakcji turystycznych, poprawy warunków zakwaterowania i zadbania o sprawniejsze połączenie środkami PKS i PKP, zwiększenia ścieżek rowerowych oraz rozbudowy bazy wypożyczalni sprzętu rekreacyjnego (głównie rowerów, kajaków sprzętu do uprawiania nordic walking, sprzętu zimowego). Jeżeli zostaną wykonane zaprezentowane przedsięwzięcia, to na pewno zwiększy się ruch turystyczny i jednocześnie nastąpi poprawa budżetu gminy i zamieszkujących rodzin $\mathrm{w}$ gminie.

Jest także duże prawdopodobieństwo, że pobyty turystów będą dłuższe i będzie jeszcze większe zainteresowanie wypoczynkiem w Puszczy Białowieskiej.

\section{Bibliografia}

Białowieski Park Narodowy, Wyd. BPN, Białowieża 2009

Gaworecki W.W., Turystyka, PWN, Warszawa 2010.

Gierasimiuk A., Udostępnianie turystyczne BPN, zagospodarowanie-problemy-plany na przyszłość, Centrum Naukowo Badawcze ZWL w Hajnówce, Hajnówka 2015.

Informacja Dyrekcji Białowieskiego Parku Narodowego, Białowieża 2013.

Jalinik M., Doradztwo w działalności turystycznej, Wydawnictwo EkoPress, BiałystokHajnówka 2016.

Jalinik M., Bialowieski Park Narodowy - turystyczna atrakcja wieloaspektowa, w: K Michałowski, B. Malinowska (red.), Markowy produkt turystyczny w pótnocno wschodniej Polsce, Wydawnictwo Politechniki Białostockiej, Białystok 2004.

Łobożewicz T., Bieńczyk G., Podstawy turystyki, WSE, Warszawa 2001.

Meyer B., Obstuga ruchu turystycznego, red., PWN, Warszawa 2006.

Panasiuk A., Ekonomika turystyki, red., PWN, Warszawa 2007.

Poskrobko B., Rejon Puszczy Białowieskiej. Mieszkańcy - Środowisko - Gospodarka, red, Wydawnictwo Politechniki Białostockiej, Białystok 1996.

Terminologia turystyczna, Zalecenia WTO, Warszawa 1995

\section{Tourist traffic in the area of the Bialowieza Forest in the light of research}

\section{Summary}

The increasing popularity of tourist trips as a form of leisure activity contributes to the continuous increase in the number of tourists. The development of civilization causes gradually increasing interest in recreation areas with contamination-free environment. This results primarily from urbanization, changes in the structure of inhabitants in favor 
of mental work to improve the economic situation. A significant factor in attracting tou ris ts to the municipality and the Bialowieza Bialowieza Forest are mainly forest areas which have natural, scenic and cultural values. Keep in mind that forest areas are for the people, but they need to be skillfully used to improve the physical and mental health, without prejudice to the principles of sustainable development.

The results showed that the area of the Bialowieza Forest should aim to increase tourist attractions, improving the conditions of accommodation and ensure the efficient combination of public bus and train, to increase bicycle lanes and expansion of the base rental of recreational equipment (mainly bicycles, kayaks, equipment for Nordic walking, and winter equipment). If presented undertakings are implemented, it will definitely increase tourist traffic and at the same time it will improve the municipal budget and the budget of the families living in the community. There is also a likelihood that the stays of tourists will be longer and will be even more interest in recreation in the Bialowieza Forest. 